\title{
COMPARISON OF BREAST MILK COMPOSITION AMONG LACTATING WOMAN IN LATVIA
}

\author{
Lìga Broka ${ }^{1 \#}$, Ilva Daugule ${ }^{1}$, Inga Ciproviča ${ }^{2}$, Daiga Kvilūna ${ }^{3}$, \\ and Ingrida Rumba-Rozenfelde \\ ${ }^{1}$ Faculty of Medicine, University of Latvia, Raiṇa bulv. 19, Rīga, LV-1586, LATVIA \\ ${ }^{2}$ Latvia University of Agriculture, Lielā iela 2, Jelgava, LV-3001, LATVIA \\ ${ }^{3}$ Children's Clinical University Hospital, Vienības gatve 45, Rīga, LV-1004, LATVIA \\ \# Corresponding author; liigabroka@gmail.com
}

Communicated by Ingrīda Rumba-Rozenfelde

\begin{abstract}
Although benefits of breast-feeding have been known for a long time and breast milk is considered as ideal nutrition for infants, the composition of breast milk is still being studied, since breast milk differs among mothers and populations, as well as during different times of lactation. Further, no study has been performed among lactating women in Latvia during recent years. The objective of the study was to determine the breast milk composition and influencing factors among lactating women in Latvia in different lactation periods, as well as to compare the results with data from other countries. Fifty breast milk samples were obtained from 44 mothers (on the $5^{\text {th }}-7^{\text {th }}$ and $11^{\text {th }}-28^{\text {th }}$ day of lactation), whose neonates were treated in the Neonatal Care Unit, Children's Clinical University Hospital, Riga. Milk analysis $(\mathrm{pH}$, density, protein, fat, and lactose concentration) was performed in the Latvia University of Agriculture. Breast milk composition among lactating women in Latvia on the $5^{\text {th }}-7^{\text {th }}$ lactation day more resembled transitional milk containing a higher amount of protein and a lower amount of fat. The composition of the studied milk samples on the $11^{\text {th }}-28^{\text {th }}$ lactation day was comparable to data from other countries. Concentration of lactose was correlated with neonatal weight and not gestational age.
\end{abstract}

Key words: breast milk composition, human milk, breast feeding, lactose.

\section{INTRODUCTION}

Many studies have highlighted advantages of human milk nutrition, and doctors all around the world recommend exclusive breast feeding during the first six months. It has been noted that the content of breast milk differs among mothers and populations, as well as during the time of lactation (colostrum vs. transitional and mature milk) (Kulski et al., 2004). The latest studies even suggest that breast milk contains more than 500 different ingredients (Bauer and Gerss, 2011).

Although fat is the most important source of energy for infants (supplying more than $50 \%$ of the necessary energy), it changes in the composition of macronutrients - fat concentration is lower in the first milk (foremilk) and higher at the end of breast-feeding (Saarela et al., 2005). Further, studies have demonstrated that fat concentration in breast milk is lower when a mother wakes, compared to the nursing time in the evening (Martin et al., 2012). Similarly, lactose concentration differs depending on the lactation day. It has been shown that lactose improves microflora of the gastrointestinal system, promotes absorption of calcium, and sustains normal metabolism (Bode, 2012). Lactose concentration also affects infant health and development of the gastrointestinal tract (Newburg et al., 2005). Breast milk composition can also be affected by factors like gestational age, weight of the neonate, formation and excretion of breast milk, and weight changes of the mother during pregnancy. Therefore, it is important to determine breast milk composition in different populations and among different individuals, as well as during different time of lactation.

The aim of the present study was to determine the breast milk composition and influencing factors among lactating women in Latvia in different lactation periods, as well as to compare the results with data from other countries.

\section{MATERIALS AND METHODS}

Study design. The study was carried out at the neonatal care unit in the Children's Clinical University Hospital in Rìga (Latvia) from September 2014 to March 2015. Breast milk samples $(50 \mathrm{ml})$ were collected from mothers of neonates on the $5^{\text {th }}-7^{\text {th }}$ and $11^{\text {th }}-28^{\text {th }}$ day of lactation. 
Analysis of milk samples. Collected milk samples were analysed in the laboratories of the Faculty of Food Technology of the Latvia University of Agriculture. Protein, fat, lactose content, $\mathrm{pH}$, and density were measured according to standard methods (LVS EN ISO 8968-1:2014, ISO 11870:2009, ISO 22662:2007, LVS ISO 5546:2010, and LVS 186:1999) for milk and dairy product evaluation. Parameters were determined in triplicate for the samples. Milk samples were collected and immediately frozen at $-20{ }^{\circ} \mathrm{C}$ until analysis.

Statistical analysis. Data were recorded and compiled in Microsoft Excel. Data statistical analysis was performed using the MedCalc programme. The ANOVA test, MannWhitney U test, Pearson correlation coefficient, and multiple linear regression tests were used as appropriate.

Results were compared to data from the American Academy of Paediatrics (Anonymous, 2009) and Illustrated Textbook of Pediatrics (Lissauer and Clayden, 2012).

Ethical considerations. The study protocol was approved by the Research Ethical Committee at the Institute of Experimental and Clinical Medicine of the University of Latvia. Mothers signed written patient consent forms.

\section{RESULTS}

Patient characteristics. In total, 50 milk samples were collected: 39 samples on the $5^{\text {th }}-7^{\text {th }}$ day of lactation and 11 samples on the $11^{\text {th }}-28^{\text {th }}$ day of lactation. The patient group included 17 mothers of premature neonates and 22 mothers of term neonates.

The mean gestational age of neonates was 35.98 weeks (SD $\pm 3.60)$, mean weight was $2.6 \mathrm{~kg}(\mathrm{SD} \pm 1.20)$, minimum weight was 950 grams and maximum weight was 4500 grams.

The neonates were admitted to the hospital for the following reasons: prematurity - 24 cases; small for gestational age - 11 cases; congenital heart disease - 6 cases; intrauterine infection - 6 cases, infectious disease (bronchiolitis, meningitis) - 3 neonates, and perinatal asphyxia -3 neonates.
Composition of milk samples. Average density and $\mathrm{pH}$ of milk samples on the $5^{\text {th }}-7^{\text {th }}$ and $11^{\text {th }}-28^{\text {th }}$ day of lactation, as well as concentration of fat, protein and lactose are shown in Table 1.

Fat concentration showed a large variability among patients (95\% confidence interval $1.605-5.470$ and 2.427-4.560 on the $5^{\text {th }}-7^{\text {th }}$ and $11^{\text {th }}-28^{\text {th }}$ lactation day, respectively).

Concentration of lactose on the $5^{\text {th }}-7^{\text {th }}$ day of lactation was higher among breast milk samples from mothers of premature neonates compared to mothers of term neonates: $7.6 \%$ $(\mathrm{SD} \pm 0,9)$ vs. $6.7 \%(\mathrm{SD} \pm 1.3)(p=0.003)$, as well as from mothers with low birth weight $(<2.5 \mathrm{~kg})$ neonates compared to neonates with a birth weight $2.5 \mathrm{~kg}: 7.8 \%$ (SD \pm $0.7)$ vs. $6.7 \%(\mathrm{SD} \pm 1.2)(p=0.002)$. Lactose concentration correlated with gestational age, birth weight, $\mathrm{pH}$, density, and protein concentration. Multiple regression analysis indicated that lactose concentration was significantly related to birth weight and $\mathrm{pH}$ but not with gestational age of the neonate.

The milk content in respect to density, $\mathrm{pH}$, protein, fat concentration did not differ in relation to type of delivery, gestational age, mother's weight, and weight increase during pregnancy.

Comparison of milk composition among Latvian women with data from other populations. The protein concentration in the samples collected on the $5^{\text {th }}-7^{\text {th }}$ and $11^{\text {th }}-28^{\text {th }}$ day of lactation was statistically significantly higher and the concentration of fat was statistically significantly lower compared to data from the American Academy of Paediatrics (Fig. 1). Concentration of lactose did not differ between Latvian and American (USA) women (Anonymous, 2009).

Composition of milk samples from Latvian women was more comparable to British data (Fig. 1). However, concentration of fat on the $11^{\text {th }}-28^{\text {th }}$ day of lactation among Latvian women was significantly higher than among British women: $4.42 \%$ versus $3.0 \%$, respectively. Protein concentration was statistically significantly higher in samples gathered on the $5^{\text {th }}-7^{\text {th }}$ day of lactation compared to British data: $2.04 \%$ versus $1.3 \%$, respectively. Lactose concentrations did not significantly differ between Latvian and British women. (Lissauer and Clayden, 2012).

Table 1

COMPOSITION OF BREAST MILK ON THE $5^{\mathrm{TH}}-7^{\mathrm{TH}}$ AND $11^{\mathrm{TH}}-28^{\mathrm{TH}}$ DAY OF LACTATION AMONG LACTATING WOMEN IN LATVIA

\begin{tabular}{l|c|c|c|c}
\hline Macroelements & $\begin{array}{c}\text { Concentration } \% \\
\left.5^{\text {th }}-7^{\text {th }} \text { day }\right) \\
\mathrm{n}=39\end{array}$ & CI (95\%) & $\begin{array}{c}\text { Concentration \% } \\
\left(11^{\text {th }}-28^{\text {th }} \text { day) }\right. \\
\mathrm{n}=11\end{array}$ & CI (95\%) \\
\hline $\mathrm{pH}$ & 6.82 & $6.3098-7.1669$ & 6.48 & $6.1023-6.9871$ \\
Density kg/m ${ }^{3}$ & 1026.15 & $1010-1055$ & 1018.56 & $1008-1043$ \\
Protein & $2.04 *$ & $1.258-2.672$ & $1.46^{*}$ & $1.078-2.432$ \\
Fat & $3.11 *$ & $1.605-5.470$ & $4.42 *$ & $2.427-4.560$ \\
Lactose & 6.95 & $5.025-9.071$ & 6.5 & $5.389-7.672$
\end{tabular}

$* p<0.01$ 


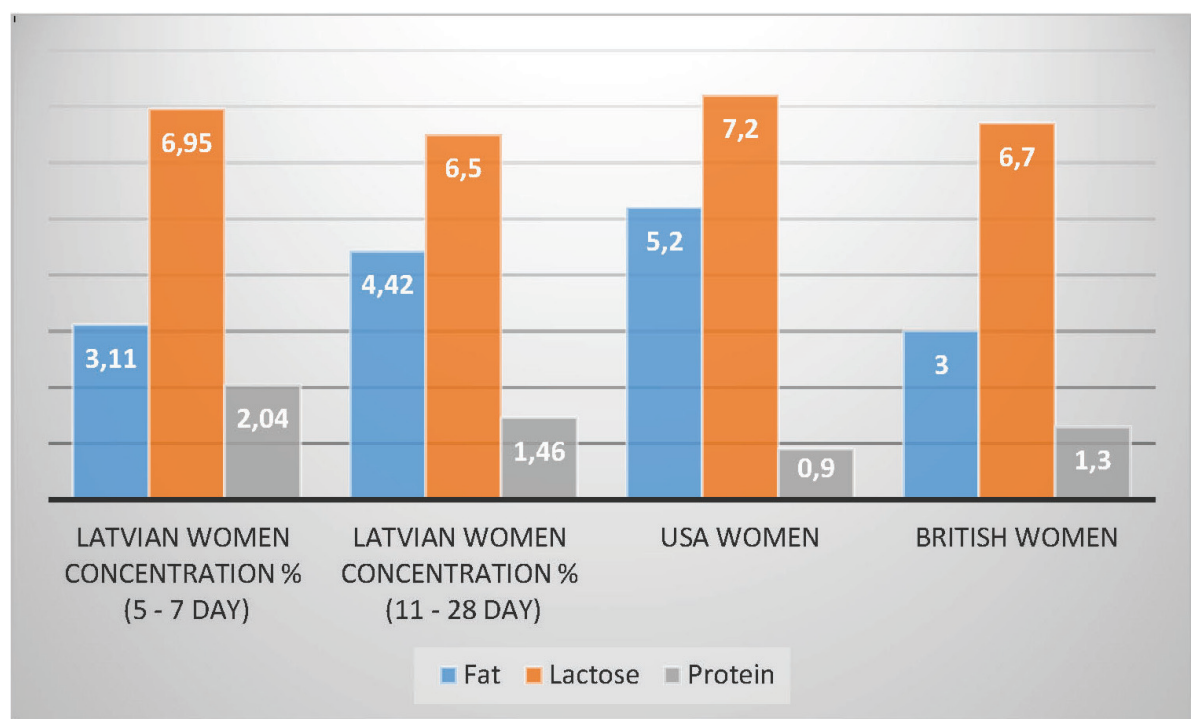

Fig. 1. Fat, lactose and protein concentration $(\%)$ in breast milk samples $\left(5^{\text {th }}-7^{\text {th }}\right.$ and $11^{\text {th }}-28^{\text {th }}$ days of lactation) in Latvian women compared to data of British (Lissauer and Clayden, 2012) and American (USA) (Anonymous, 2009) women.

\section{DISCUSSION}

Composition of breast milk in the population of Latvia has not been studied for more than 20 years. Although data from the present study show that the composition of breast milk among lactating women in Latvia is comparable to data from literature, several differences were observed. Higher concentration of protein and lower concentration of fat in milk samples from the $5^{\text {th }}$ to $7^{\text {th }}$ day than in comparable samples from the USA and UK might be explained by transitory milk that could still be present in the studied samples. Further, lower fat concentration in our samples compared to USA data might reflect dietary differences between the populations. In addition, concentration of fat showed large variability between samples, thus suggesting that fat concentration could depend on other factors like nutrition of the mother. Nevertheless, since fat is the main source of energy in infants (supplying more than $50 \%$ of the necessary energy), low fat intake can possibly affect the nutritional status of neonates and infants. Therefore, it could be advisable to perform individual milk analysis among patients with poor weight gain, which would allow to evaluate the need for milk supplements. In addition, mothers of infants with poor weight gain should be educated to express the milk at the end of every feeding, since it contains more fat.

Concentration of lactose in the studied population was higher in samples from mothers who had a neonate with low birth weight $(<2.5 \mathrm{~kg})$, compared to that in neonates with a birth weight $>2.5 \mathrm{~kg}$. Since premature infants have a lower lactase concentration, it was expected that lactose concentration is correlated with gestational age. Higher lactose concentration in samples from mothers with lowweight neonates might be explained by beneficial effects of lactose to the gastrointestinal tract, suggested by positive effect on the development of hereditary immune response and intestinal bacteria (Cederlund et al., 2013).

Nevertheless, lack of normal amounts of lactase in neonates might be associated with a transitory lactose intolerance, causing watery diarrhoea and possible affecting weight gain.
Since the studied milk samples represent milk composition from mothers with unhealthy neonates, the results cannot be used as a reference for the general population. Nevertheless, the data should be considered in the neonatal care unit when calculating the necessary amount of calories for newborns based on the data from American Academy of Paediatrics. However, a large variability of concentration of macronutrients among breast milk samples demonstrates that breast milk is a unique nutritional source for each neonate and infant.

\section{CONCLUSIONS}

Composition of breast milk from Latvian mothers on the $5^{\text {th }}-7^{\text {th }}$ day of lactation represents transitory breast milk with a higher concentration of protein and a lower concentration of fat. Fat content shows large interpatient variability, therefore, individual analysis of fat concentration should be recommended for neonates with poor weight gain to evaluate the necessity for milk fortification. Concentration of lactose is independently correlated with neonatal birth weight.

In order to generalize data about composition of breast milk to the population of Latvia, samples from mothers with healthy neonates should be analysed.

\section{ACKNOWLEDGMENTS}

The study was supported by a grant from the Latvian Academy of Sciences, State Research programme BIOMEDICINE. We thank all the mothers who agreed to participate in the study and donated milk samples.

\section{REFERENCES}

Anonymous (2009). Pediatric Nutrition Handbook. 6th edn. Kleinman, R. E. (Ed.). American Academy of Pediatrics, Committee on Nutrition, Elk Grove Village, IL. 1470 pp; at pp. 1201-1203. 
Bauer, J., Gerss, J. (2011). Longitudinal analysis of macronutrients and minerals in human milk produced by mothers of preterm infants. Clin. Nutr., 30 (2), 215-220.

Cederlund, A., Kai-Larsen, Y., Printz, G., Yoshio, H., Alvelius, G., Lagercrantz, H., Strömberg, R., Jörnvall, H., Gudmundsson, G. H., Agerberth, B. (2013). Lactose in human breast milk, an inducer of innate immunity with implications for a role in intestinal homeostasis. PLoS One, 8 (1), e53876.

Kulski, J. K., Hartmann, P. E. (2004). Changes in human milk composition during the initiation of lactation. Austr. J. Exp. Biol. Med. Sci., 59 (1), $101-114$.

Bode, L. (2012). Human milk oligosaccharides: Every baby needs a sugar mama. Glycobiology, 22 (9), 1147-1162.
Martin, M. A., Lassek, W. D., Gaulin, S. J., Evans, R.W., Woo, J. G., Geraghty, S. R., Davidson, B. S., Morrow, A. L., Kaplan, H. S., Gurven, M. D. (2012). Fatty acid composition in the mature milk of Bolivian forager-horticulturalists: Controlled comparisons with a US sample. Matern. Child. Nutr., 8 (3), 404-418.

Newburg, D. S., Ruiz-Palacios, G. M., Morrow, A. L. (2005). Human milk glycans protect infants against enteric pathogens. Annu. Rev. Nutr., 25, 37-58.

Saarela, T., Kokkonen, J., Koivisto, M. (2005).Macronutrient and energy contents of human milk fractions during the first six months of lactation. Acta Paediatr., 94 (9), 1176-1181.

Lissauer, T., Clayden, G. (2012). Illustrated Textbook of Paediatrics. $4^{\text {th }}$ edn. Mosby Elsevier, Edinburgh, London. 552 pp.; at pp. 206-207.

Received 17 December 2016

\section{KRŪTS PIENA SASTĀVA SALĪDZINĀJUMS MĀTĒM LATVIJĀ DAŽĀDOS LAKTĀCIJAS PERIODOS}

Pēdējo 20 gadu laikā krūts piena sastāvs Latvijā nav pētīts. Mūsu pētījuma mērkis bija noteikt krūts piena sastāvu mātēm Latvijā dažādos laktācijas periodos, kā arī salīdzināt iegūtos rezultātus ar citu valstu datiem. Piena paraugi tika iegūti no 44 mātēm (39 paraugi 5.-7. laktācijas dienā, 11 paraugi 11.-28. laktācijas dienā), kuru jaundzimušie ārstējās Bērnu klīniskajā universitātes slimnīcā jaundzimušo nodaḷās. Piena analīze veikta Latvijas Lauksaimniecības universitātē (pH, blīvums, olbaltumvielu, tauku, glikozes un laktozes koncentrācija). Piena paraugu sastāvs no jaundzimušo mātēm 5.-7. laktācijas dienā vairāk atbilda pārejas piena sastāvam. Laktozes koncentrācija bija augstāka piena paraugos no mātēm ar zema svara (<2,5 kg) jaundzimušajiem, salīdzinot mātēm, kuru jaundzimušie bija ar svaru $>2,5 \mathrm{~kg}$. Tauku koncentrācija izteikti atškīrās pētītajos piena paraugos no dažādām mātēm, kā arī bija zemāka, salīdzinot ar citu valstu datiem. Tā kā tauki ir galvenais enerğijas avots zīdainiem (sniedz vairāk nekā 50\% no nepieciešamās enerğijas), zemāks tauku saturs pienā, iespējams, var radīit samazinātu kaloriju uzṇemšanu jaundzimušajiem un zīdaiņiem, kas var būt saistīts ar nepietiekamu svara pieaugumu. Tādēl varētu būt ieteicams veikt individuālu piena analīzi pacientiem ar sliktu svara pieaugumu — tas ḷautu izvērtēt nepieciešamību pēc piena bagātinātājiem. Lai datus par mātes piena sastāvu varētu vispārināt, būtu jāvāc piena paraugi mātēm ar jaundzimušajiem bez veselības problēmām. 